\title{
Ochrana prírody, krajiny a životného prostredia a jej spolo- čenská reflexia na Slovensku v r. 1990 - 2020
}

\section{Mikuláš Huba}

\section{Envigogika 15 (1) - Recenzované články/ Reviewed Papers}

Publikováno / Published 3

31. 8.2020

DOI: $\underline{10.14712 / 18023061.605}$

\begin{abstract}
Abstrakt
Slovenská príroda, krajina a životné prostredie, ako aj organizácie a iniciatívy na ich ochranu prešli za uplynulých 30 rokov zložitým vývojom. Podobne zložito sa vyvíjala aj percepcia tejto problematiky zo strany verejnosti. Vari najvýstižnejšie sa dá tento vývoj charakterizovat' slovíčkom nejednoznačný. Pokrok pri znižovaní znečistenia ovzdušia, vôd a d'alších zložiek životného prostredia sprevádzala bezprecedentná neúcta $\mathrm{k}$ iným jeho zložkám, najmä k zeleni a úrodným orným pôdam, celkové dlhodobé podfinancovanie starostlivosti o ŽP a zaostávanie v budovaní environmentálnej infraštruktúry (najmä kanalizácií a čistiarní odpadových vôd) ako aj riešenia problematiky starých environmentálnych zátaží.
\end{abstract}

Príspevok sa zameriava na stručnú charakteristiku stavu a vývoja jednotlivých zložiek životného prostredia, úspechy a neúspechy pri ich ochrane, ako aj na úlohu jednotlivých aktérov tohto procesu. Súčast́ou príspevku sú aj výsledky niektorých výskumov, zameraných na reflexiu tejto problematiky zo strany verejnosti.

\section{Klíčová slova}

Př́roda; krajina; životní prostředí; ochrana; relevantní aktéři; společenská reflexe; Slovensko; 1990-2020

\begin{abstract}
Slovak nature, landscape and environment, as well as organizations and initiatives for their protection have undergone complex developments over the past 30 years. Perception of the issue by general public was similarly complex. In an attempt to be precise, this development should be characterized ambiguously. Progress in reducing air, water and other environmental pollution has been accompanied by unprecedented disrespect for its other components, in particular for vegetation, fertile arable land, which is accompanied by an overall long-term underfunding of environmental care and lagging behind in building environmental infrastructure (especially sewers and wastewater treatment plants) as well as in finding solutions to the issue of old environmental burdens.
\end{abstract}

This article focuses on a brief description of the state and development of different components of the environment, successes and failures in their protection, as well as the 
role of specific actors in this process. The author also include the results of some of the research which focused at reflection of these issues by the public.

\section{Key words}

Nature; nature landscape; landscape environment; environment protection; protection relevant actors; relevant actors social reflection; social reflection; Slovakia; Slovakia years 1990 - 2020; years $1990-2020$ 


\section{Úvod}

Uplynulých 30 rokov vývoja životného prostredia (ŽP) na Slovensku možno hodnotit' z rôznych aspektov a s využitím rôznych metodických postupov. Ako jeden z možných konceptuálnych rámcov takéhoto hodnotenia možno použit zjednodušený model, ktorý vznikol na pôde OECD a ktorý postupne hodnotí sily a faktory vplývajúce na stav ŽP (Driving forces - D), následne stav životného prostredia (State - S) a napokon odozvu spoločnosti (Response - R).

Iná možnost' je hodnotit́ najskôr meratel'ný stav a vývoj ŽP prostredníctvom viac-menej objektívnych veličín, následne potom technickú a inštitucionálnu infraštruktúru starostlivosti o životné prostredie a účast', postoje, vnímanie i aktivity spoločnosti - až po úroveň jednotlivcov, resp. ich reprezentatívnych súborov. Kedže ide o vel'mi širokú problematiku, ak chceme získat' ako-tak komplexný obraz o nej, potom za relevantné je treba považovat́ celé spektrum subjektov (od verejnej správy, cez mimovládne organizácie, školy a akadémiu až po médiá).

Napokon možno aplikovat aj metódu SWOT analýzy na porovnanie silných a slabých stránok, príležitostí a ohrození týkajúcich sa hodnotenej problematiky.

Vzhladom na komplexnost' environmentálnej problematiky je pri všetkých úvahách o ŽP mimoriadne dôležité uvažovat́ v súvislostiach a zamerat' sa na kauzálne vztáahy a väzby. $\checkmark$ príspevku sa dajú nájst' všetky vyššie uvedené prístupy. Niektoré vo viac explicitnej, iné len $v$ implicitnej podobe.

\section{Stav a vývoj životného prostredia a faktory, ktoré ho spôsobujú}

Spomedzi faktorov, ktoré spôsobujú súčasný stav ŽP, možno na prvom mieste spomenút prírodné podmienky a históriu využívania krajiny človekom. $\mathrm{S}$ tým sa $\mathrm{v}$ prípade ŽP zvyknú spájat́ spôsoby a zdroje znečistovania, alebo iných druhov jeho devastácie, ako aj odozva krajiny i spoločnosti na ne.

Čo sa týka zmien vplyvu negatívnych impaktov na ŽP je ho možné za uplynulých 30 rokoch hodnotit' ako prevažne pozitívny. Možno to dokumentovat́ výsledkami monitoringu i štatistickými údajmi, týkajúcimi sa takmer všetkých zložiek prírodného prostredia a jeho kvality: ovzdušia, vody, pôdy, bioty...

Z porovnania vývoja 105 relevantných a kvantifikovatel'ných ukazovatelov ekonomického, sociálneho a environmentálneho charakteru $v$ priebehu 90 . rokov minulého storočia na Slovensku (Huba 2002) vyšiel práve vývoj v posledne menovanej oblasti ako relatívne najpozitívnejší. Možno to pripísat́ najmä dvom skutočnostiam: v prvom rade hospodárskej recesii a ekonomickej transformácii $\vee 1$. polovici 90 . rokov 20. storočia, ktorá sa dotkla najmä odvetví významne ovplyvňujúcich životné prostredie (priemysel, pol'nohospodárstvo, stavebníctvo, táǎba surovín...) a až na druhom mieste samotnému zlepšeniu starostlivosti o ŽP (nové inštitúcie, zákony a ich uplatňovanie). 


\section{Manažment životného prostredia}

\section{Opatrenia na zlepšenie stavu ŽP, pozitíva a skutočnosti, ktoré ich relativizujú}

Starostlivost́ o životné prostredie u nás začala nadobúdat' systematickejšiu podobu až po r. 1989, kedy sa v pomerne krátkom čase podarilo dobudovat́ chýbajúci inštitucionálnoorganizačno-legislatívny rámec starostlivosti oň.

Tlak na zlepšovanie stavu ŽP a starostlivosti oň sa d’alej posilnil v súvislosti s predvstupovým procesom a následne s členstvom Slovenskej republiky (SR) v EÚ. Toto obdobie prinieslo so sebou aj nové disponibilné zdroje financovania, ktoré aspoň čiastočne zvrátili dlhodobo pretrvávajúci stav podfinancovania aktivít v rezorte ŽP.

Prevažne pozitívny (miestami až výrazne pozitívny) vývoj v tejto oblasti (najmä v prvej polovici sledovaného obdobia (pozri tab. 1), však čiastočne relativizujú niektoré skutočnosti (pozri graf 1 a 2). V prvom rade tá, že vzhl'adom na to, negatívne trendy vo sfére ŽP kulminulovali práve v zlomovom období 1988 - 1989, na následné zlepšenie jeho stavu stačili niekedy pomerne nenáročné opatrenia. (Čím sa situácia v ČSFR a v jej nástupníckych štátoch zásadne líši od situácie v USA či v Západnej Európe, kde sa podobný proces začal o dve dekády skôr - pozn. aut.). Druhá relativizujúca skutočnost́ je tá, že okrem zlepšenia (miestami naozaj výrazného) nastalo v niektorých ukazovateloch aj zhoršenie stavu, resp. objavili sa nové formy devastácie ŽP a nové kategórie rizík, súvisiace o.i. s posilnením spotrebitel'ských očakávaní a konzumne orientovaných vzorcov správania obyvatel'ov, s intenzívnym rozvojom individuálnej automobilovej dopravy na úkor verejnej dopravy, s nadmernou tážbou dreva v lesoch, s nedoriešenou problematikou tzv. starých environmentálnych zátáaží, s vel'kými trvalými zábermi kvalitných pol'nohospodárskych pôd, s nedostatočne regulovanou výstavbou v národných parkoch, či s používaním GMO alebo celej škály nových druhov produktov, napr. plastových obalov na jedno použitie.

Nejednoznačne a nie vždy priaznivo sa vyvíjali aj postoje verejnosti $k$ ochrane a ochrancom ŽP. Novú hrozbu i mnohé reálne škody na prírode, krajine a životnom prostredí spôsobili aj nie dost' účinne regulované agresívne až devastačné aktivity niektorých investorov či tzv. developerov. Ďalšia skutočnost', relativizujúca celkovo prevažne pozitívny vývoj, je tá, že vychádzame takmer výlučne z meratel'ných ukazovatel'ov kvantitatívneho charakteru (napr. imisie na $\mathrm{km}^{2}$ ) a menej sa už hovorí o kvalite. Markantným príkladom sú napríklad národné parky a maloplošné chránené územia, počet a výmera ktorých vzrástli za uplynulé tri desat́ročia približne dvojnásobne, ale režim ich ochrany je nad’alej málo účinný, a tak ich existencia miestami hraničí s formalizmom. A napokon, pozitívnost́ vývoja $v$ celej environmentálnej sfére čiastočne relativizuje aj porovnanie s porovnatel'nými krajinami na západ on nás, kde s intenzívnou starostlivostón o ŽP začali podstatne skôr.

Tab. č. 1: Celková emisie základných znečist́ujúcich látok v SR v rokoch 1989-2016 v tis. t

\begin{tabular}{|c|c|c|c|c|c|c|c|c|}
\hline & 1989 & 1993 & 2001 & 2002 & 2003 & 2004 & 2005 & 2016 \\
\hline TZL & 317,4 & 139,7 & 63,6 & 55,3 & 51,0 & 51,7 & 60,9 & 34,5 \\
\hline $\mathrm{SO}_{2}$ & 565,1 & 319,3 & 131,2 & 103,3 & 108,1 & 96,9 & 89,0 & 27,1 \\
\hline $\mathrm{NO}_{\mathrm{x}}$ & 202,6 & 219,0 & 108,4 & 100,8 & 97,7 & 97,7 & 97,5 & 61,3 \\
\hline $\mathrm{CO}$ & 543,9 & 350,0 & 309,3 & 286,6 & 301,8 & 302,7 & 290,1 & 239,7 \\
\hline
\end{tabular}

Zdroj: SHMÚ, 2018 


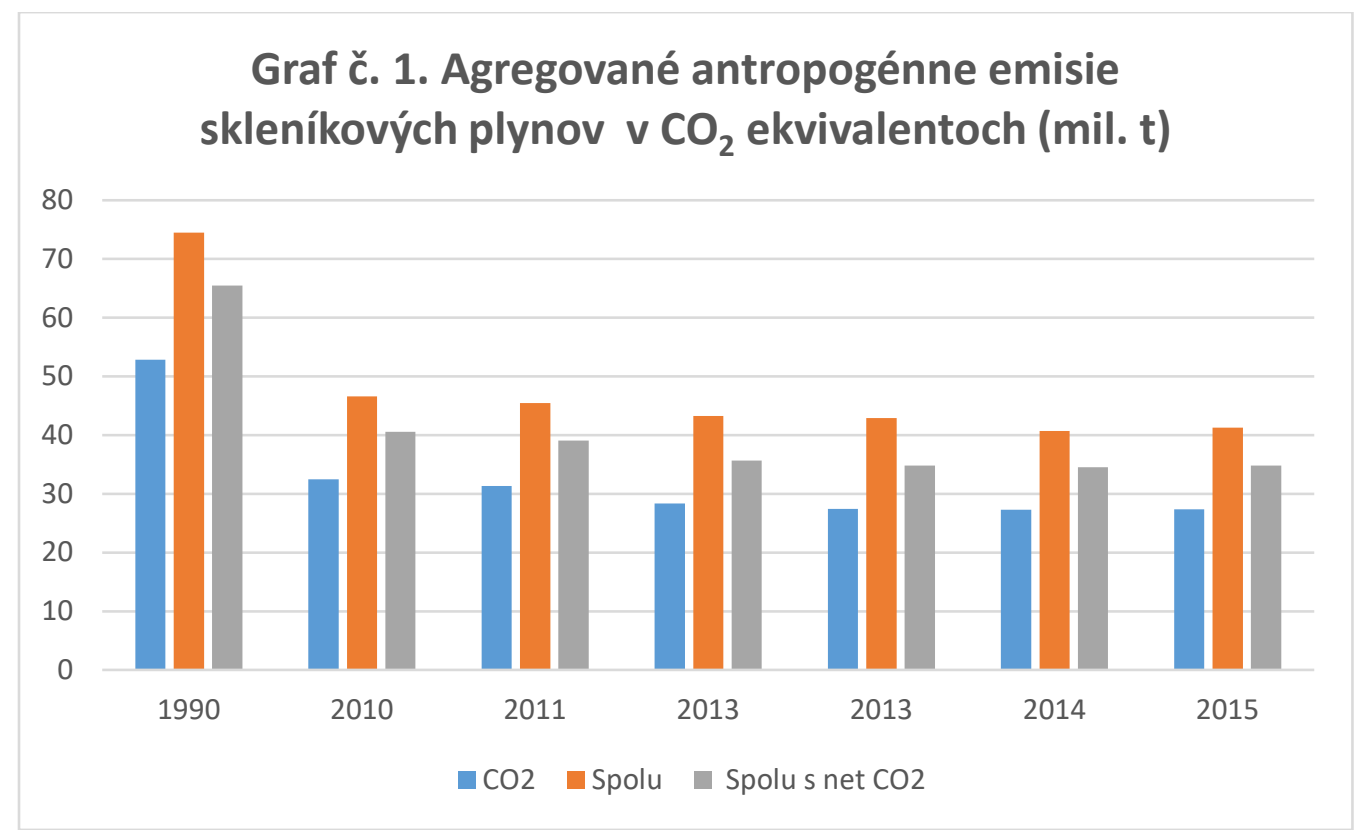

Zdroj: SHMÚ, 2019

Podobne, ako v celej EÚ, aj na Slovensku došlo za uplynulých 30 rokov k poklesu znečistenia ovzdušia z priemyslu, energetiky i dopravy a k nárastu znečistenia, súvisiaceho s domácnost́ami, službami a obchodom. Čo sa týka jednotlivých ukazovatel'ov znečistenia, najvýraznejšie zlepšenia nastalo pri oxide siričitom. Naopak, emisie oxidov dusíka v uplynulých dvoch desat́ročiach stagnovali a v prípade tuhých znečist́ujúcich látok dokonca vzrástli. (SHMU, 2004 - 2016).

Celkovo pozitívny vývoj vo sfére znečistenia ovzdušia v SR relativizuje aj jeho nerovnomerné rozloženie $v$ čase a priestore. Slovensko sa po geomorfologickej stránke vyznačuje striedaním pohorí, nížin, kotlín a údolí s často inverzným zvrstvením ovzdušia, čo má vel'mi negatívny vplyv na kvalitu ovzdušia. Okrem toho, že sa tu koncentruje obyvatel'stvo, koncentrujú sa tu aj zdroje znečistenia na báze energetiky, táǎ̌kého priemyslu, dopravy, vykurovania a i. Regióny s najväčším znečistením boli vyhlásenie za Oblasti riadenia kvality ŽP. Na Slovensku ich máme 12. Experti z občianskeho združenia Centrum pre trvalo udržatel'né alternatívy (CEPTA) analyzovali metodikou Svetovej zdravotníckej organizácie situáciu v oblastiach s riadenou kvalitou ovzdušia našich krajských miest na základe údajov oficiálneho monitoringu SHMÚ. Hodnotili dopady prachových častíc $\mathrm{PM}_{2,5}$ a $\mathrm{PM}_{10}$ a oxidov dusíka $\mathrm{NO}_{\mathrm{x}}$, teda troch hlavných $\mathrm{s}$ energetikou a spal'ovanie tuhých palív $\mathrm{v}$ domácnostiach. Z výsledkov ich analýz vyplýva, že na Slovensku kvôli znečistenému ovzdušiu predčasne umiera viac ako 5000 osôb ročne. Spolu s Pol'skom, Českom a Mad'arskom patríme ku krajinám s najviac znečisteným ovzduším v EÚ. Dlhodobo prekračujeme predovšetkým limity znečistenia prachovými časticami (PM). Podl’a OECD nás v roku 2015 stálo znečistenie ovzdušia z dôvodu predčasných úmrtí 9,279 mld. EUR, čo predstavovalo takmer 6,5 \% HDP krajiny znečisttujúcich látok v ovzduší našich miest, ktorých pôvodcami sú predovšetkým doprava, priemysel a energetika (CEPTA, 2019). 


\section{Graf č. 2. Vývoj vo vypúšt́aní čistených a nečistených odpadových vôd do vodných tokov}

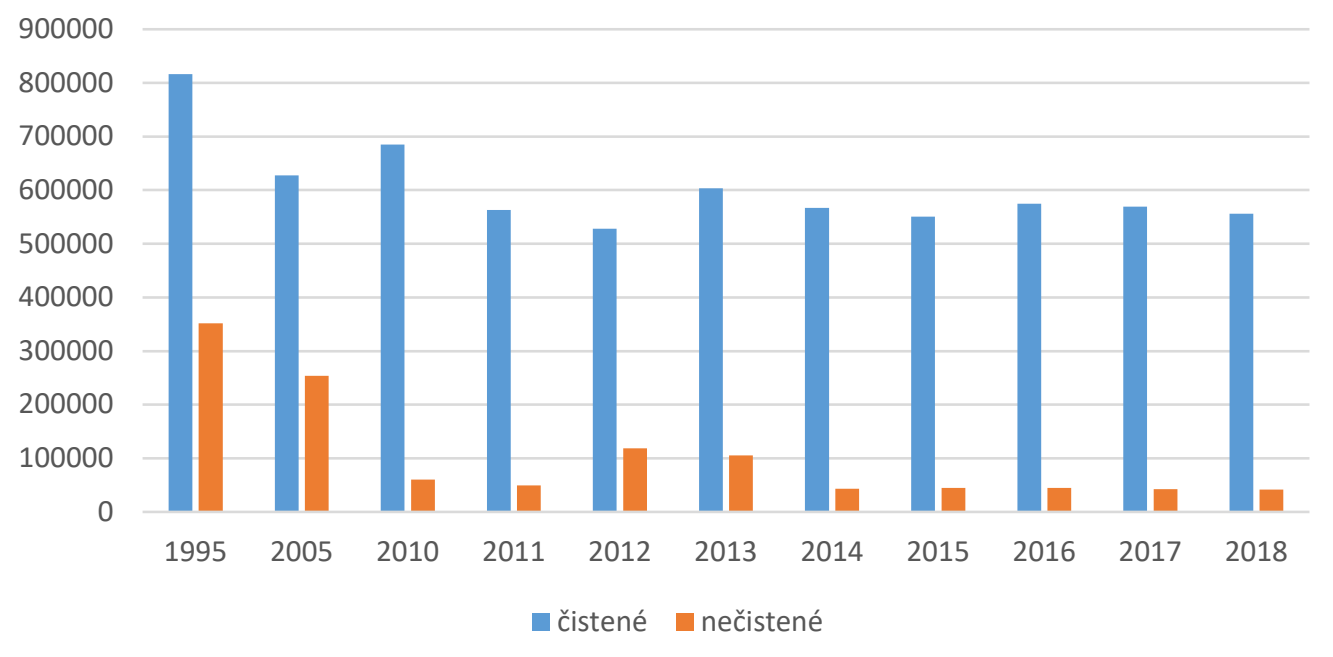

Zdroj: MŽP, 2019

Aj ked' kvalita povrchových vôd sa na Slovensku za uplynulých 30 rokov citel'ne zlepšila, stále však cca $12 \%$ z nich ešte vykazuje zlý, alebo vel'mi zlý ekologický stav. Ešte horšia je situácia v prípade podzemných vôd, kde až $22 \%$ rozlohy príslušných vodných útvarov vykazuje zlý chemický stav (MŽP, SAŽP, 2016).

Zlá situácia pretrváva vo sfére záberu pol'nohospodárskych pôd na nepol'nohospodárske účely (najmä na výstavbu), pri nadmernej táaze dreva a vysokom podiele tzv. kalamitných táažieb, $v$ hospodárení $s$ odpadmi, kde SR, napriek určitému zlepšeniu v poslednom období, nad'alej patrí v rámci EÚ ku krajinám s najnižším podielom separácie a recyklácie komunálneho odpadu a s najvyšším podielom nežiaduceho skládkovania.

Vo sfére ochrany prírody sú v kontraste priaznivé kvantitatívne ukazovatele s nepriaznivými kvalitatívnymi. Podiel rozlohy chránených území z celkovej rozlohy štátu je $\checkmark$ rámci EÚ nadštandardný, podobne ako počet národných parkov (9). Na druhej strane je alarmujúce, že a 19,3\% druhov rýb, 44,4 \% druhov obojživelníkov, 41,7 \% druhov plazov, $24,2 \%$ druhov vtákov a 22,2 \% druhov cicavcov sa v r. 2014 nachádzalo v kategórii ohrozených druhov živočíchov (MŽP, SAŽP, 2016).

Na podrobnejšie zhodnotenie 30-ročného vývoja Slovenska v jednotlivých oblastiach, relevantných z hl'adiska životného prostredia, by nestačil ani dvojnásobný rozsah tohto príspevku. Vo všeobecnosti však možno konštatovat', že napriek evidentnej ekonomickej a spoločenskej transformáciu, sa Slovensko dostatočne nevyrovnalo s industriálnym dedičstvom z čias budovania komunizmu. Hospodárstvo na Slovensku je nad'alej surovinovo i energeticky pomerne náročné a stále aktuálny je problém starých environmentálnych zátaží, ako aj novo generovaného odpadu - jadrový nevynímajúc. Podobne to vyzerá aj v mentálnej rovine: spôsob uvažovania z čias industriálnej éry sa spojil s nárastom konzumných očakávaní a s tým spojeným množstvom (aj environmentálnych) problémov. Čo sa týka známych káuz a problémov spred 30 rokov (Gabčíkovo, jadrové elektrárne, Tatry, záber polnohospo- 
dárskej pôdy na nepol'nohospodárske účely, hynutie lesov a nadmerná tažba dreva, znečistenie vôd i ovzdušia, degradácia pôdy, likvidácia vol'ne rastúcej zelene a mnohé d'alšie) zostávajú problémami aj dnes. Navyše k ním pribudli mnohé d’alšie: od prudkého nárastu automobilizmu, cez produkciu plastového odpadu až po nevídanú exploatáciu národných parkov komerčným cestovným ruchom.

\section{I nštitucionálna stránka starostlivosti o ŽP vrátane personálnych otázok}

Na rozdiel od USA, Kanady, Austrálie či niektorých krajín západnej Európy, kde inštitucionálna stránka starostlivosti o ŽP systematicky funguje od začiatku 70. rokov minulého storočia, $v$ bývalom Československu ústredné orgány starostlivosti o ŽP dlho absentovali, a tak táto aktivita mala až do konca roku 1989 len nekomplexný, nekoordinovaný a parciálny charakter. Navyše, tých niekolko zákonov, ktoré sme vo sfére životného prostredia mali (najmä ovzdušie, voda, ochrana prírody), patrili do gescie rôznych rezortov (priemysel, lesné a vodné hospodárstvo, kultúra...).

Absurdnou reakciou na tento stav, svojím formalizmom typickou pre prednovembrový režim, bolo vytvorenie ministerstva vnútra a životného prostredia v r. 1988, kde na úseku ŽP na Slovensku pracovalo len osem pracovníkov a žiadny z nich nebol naslovovzatým odborníkom $v$ tejto oblasti!

Skutočný ústredný orgán štátnej správy pre životné prostredie - najskôr Slovenská komisia pre životné prostredie (SKŽP), neskôr Ministerstvo životného prostredia SR (MŽP), vznikol až 1. 4. 1990 (tri mesiace po vzniku MŽP v Českej republike). Federálny výbor pre ŽP vznikol až po parlamentných volbách v júni 1990. V tom istom roku na Slovensku vznikla aj Slovenská inšpekcia životného prostredia (SIŽP).

Inštitúcie vo sfére životného prostredia (ŽP) prešli za uplynulé tri desat'ročia pomerne dynamickým vývojom. Tak napr. k 1. 1. 1991 sa na Slovensku podarilo uzákonit' a uviest' do života tzv. osobitnú štátnu správu pre životné prostredie, reprezentovanú samostatnými okresnými a obvodnými úradmi ŽP, ktoré na rozdiel od tzv. všeobecnej miestnej štátnej správy nepodliehali ministerstvu vnútra. Postupne sa dobudovala (aj na úrovni krajov) Slovenská inšpekcia životného prostredia. Ako odborno-metodicko-organizačné zložky v rámci rezortu ŽP pôsobí Slovenská agentúra pre životné prostredie, Štátna ochrana prírody SR a d’alšie odborné organizácie (napr. Slovenský hydrometeorologický ústav, Štátny geologický ústav Dionýza Štúra, či Výskumný ústav vodného hospodárstva). Od roku 2016 pôsobí v štruktúre MŽP aj analytický útvar s názvom Inštitút environmentálnej politiky. Ako podporný nástroj na financovanie starostlivosti o ŽP slúži Štátny fond životného prostredia (neskôr Envirofond). Na úseku odpadového hospodárstva vznikol a niekolko rokov fungoval (avšak v súvislosti s novou odpadovou legislatívou neskôr zanikol) Recyklačný fond SR.

Ale starostlivost́ o ŽP sa inštitucionalizovala aj na úrovni miestnej a regionálnej samosprávy a tiež na parlamentnej úrovni, kde začiatkom roka 1990 vznikol výbor pre životné prostredie ( $v$ júni 1990 doplnený o slovné spojenie: „....a ochranu prírody“), ktorý bol po volbách r. 2006 zrušený, resp. začlenený do výboru pre pôdohospodárstvo (dnes Výbor NR SR pre pôdohospodárstvo a životné prostredie - pozn. aut.).

Možno zovšeobecnit', že charakter starostlivosti o životné prostredie sa menil podla toho, aké priority vyznávala a vyznáva tá-ktorá vláda či samospráva. A následne podla toho, kto, s akou prípravou, kompetenciou, víziou, morálnou integritou a autoritou stál na jeho čele. Členmi vlády, zodpovednými za ŽP, boli postupne Vladimír Ondruš (Verejnost́ proti násiliu, 1989 - 1990), Ivan Tirpák (Krest́anskodemokratické hnutie, 1990 - 1992), Jozef 
Zlocha (Hnutie za demokratické Slovensko, 1992 - 1994), Juraj Hraško (Strana demokratickej l'avice, 1994) a po ňom až do volieb v r. 1998 opät' Jozef Zlocha. V r. 1998 - 2006 tento post zastával László Miklós (Strana mad’arskej komunity). Vo volebnom období 2006 - 2010 pripadlo riadenie MŽP Slovenskej národnej strane a v priebehu troch rokov sa na jeho čele vystriedali traja ministri (Jaroslav Izák, Ján Chrbet a Viliam Turský), pričom všetci z nich boli postupne odvolaní (najmä) z dôvodu netransparentného hospodárenia s verejnými prostriedkami a celkovej nespôsobilosti viest' zverený rezort. Po odvolaní posledne menovaného nominanta za SNS sa vtedajší premiér Robert Fico rozhodol vyňat' rezort životného prostredia z rozhodovania svojho koaličného partnera (SNS) a podriadit' ho strane Smer-SD. Po zastupujúcom ministrovi ŽP, ktorým bol niekolko týždňov podpredseda vlády Dušan Čaplovič, boli do funkcie ministra ŽP vymenovaný d’alší nominanti najsilnejšej vládnej strany Smer-SD, Jozef Medved' a Vladimír Chovan (2009 - 2010). Za vlády Ivety Radičovej pripadol rezort strane Most-Híd (Zsolt Simon, József Nagy, 2010 - 2012). V „jednofarebnej“ vláde Smeru-SD v r. 2012-2016 rezort videl Peter Žiga a v nasledujúcej koaličnej vláde László Solymos (Most-Híd), ktorý sa v roku 2018 stal aj podpredsedom vlády. V súčasnej vláde Igora Matoviča je ministrom ŽP Ján Budaj (Hnutie Obyčajní l'udia a nezávislé osobnosti, 2020 $-)$.

Čo sa týka dížky pôsobenia, najdlhšie vo svojich funkciách zotrvali ministri Miklós a Zlocha, najkratšie (ak nerátame "zastupujúceho" Dušana Čaploviča) Ondruš, Hraško, Medved', Chovan, Simon a nominanti SNS.

Kým za pôsobenia všetkých ministrov v r. 1990 - 2006 patril rezort a jeho predstavitelia $\mathrm{k}$ najmenej nápadným a najmenej medializovaným $\mathrm{v}$ rámci jednotlivých vlád, za čias 1. vlády Roberta Fica sa to zásadne zmenilo. Dosial' najviac škandalizovanou kauzou rezortu je zjavne nevýhodný, netransparentný a mimoriadne podozrivý predaj emisných kvót nedôveryhodnej sprostredkovatel'skej firme Interblue, v súvislosti s ktorým musel svoje kreslo opustit́ minister Ján Chrbet. Aj vztáahy s environmentálnymi mimovládnymi organizáciami (EMVO) sa počas pôsobenia 1. vlády Roberta Fica dostali na dosial' najhoršiu úroveň od vzniku rezortu ŽP v r. 1990. Ale najviac negatívny dosah mali čistky v štátnej správe a $\checkmark$ rezortom ŽP riadených organizáciách, najmä $v$ Štátnej ochrane prírody SR. Koncom inkriminovaného obdobia došlo dokonca $k$ dočasnému a svojvol'nému zrušeniu samostatného rezortu ŽP! Ministerstvo však vzápätí obnovila vláda Ivety Radičovej.

\section{Legislatívna, ekonomická a d’alšie stránky starostlivosti o ŽP}

Legislatívna stránka starostlivosti o ŽP prekonala za uplynulých 30 rokov ešte búrlivejší vývoj, ako tomu bolo v prípade väčšiny ostatných oblastí života spoločnosti. Po novembri 1989 sa v tejto sfére začínalo takmer "od nuly", kedže väčšinu štandardných environmentálnych právnych noriem (vrátane strešného zákona o životnom prostredí) Slovensko postrádalo. Tie, ktoré jestvovali (napr. vodný zákon), sa bud’ obchádzali zneužívaním inštitútu výnimiek, alebo boli tážko vymáhatel'né (napr. zákon o ochrane prírody). Preto zmenám a pokroku, ktorý sa v tejto oblasti vo sfére ŽP v r. 1990 - 1992 udial, sa zvykne oprávnene hovorit́ legislatívna revolúcia. $\vee$ tejto súvislosti nemožno nespomenút fakt, že významnú hybnú silu v tomto procese predstavoval Federálny výbor pre životné prostredie pod vedením Josefa Vavrouška. Dôležitá bola aj spolupráca slovenského s českým MŽP, ktoré viedol Bedřich Moldan (neskôr Ivan Dejmal) s kvalitným programom i legislatívnym odborom.

Budovanie právneho systému vo sfére ŽP malo počas uplynulých troch desat́ročí dve hlavné fázy: už spomínanú úvodnú v rokoch 1990 - 1992 a potom fázu súvisiacu s prípravou nášho vstupu do EÚ, ktorá kulminovala v rokoch 2002 - 2003. Určité oživenia nastalo aj počas krátkeho obdobia vlády Jozefa Moravčíka v r. 1994, kedy boli prijaté dva dôležité 
zákony: o posudzovaní vplyvov na životné prostredie (EIA) a o ochrane prírody a krajiny. Naopak, za obdobie regresu možno v tejto oblasti označit II. vládu Vladimíra Mečiara a I. a II. vládu Roberta Fica. Vláda Ivety Radičovej trvala príliš krátko na to, aby mohla uskutočnit' zásadnejšie zmeny. Za jej pozitívum možno označit znovuobnovenie samostatného rezortu ŽP a zlepšenie spolupráce s EMVO. Motívom pre zvýšenie aktivity (aj) MŽP bolo slovenské predsedníctvo $v$ Rade EÚ $v$ druhom polroku 2016. Následne MŽP a vláda prijali aj pomerne ambiciózny strategický rozvojový dokument (skrátene Envirostratégia 2030).

Z dôležitých právnych noriem prijatých už v priebehu 90-tych rokov 20. storočia možno spomenút aspoň strešný (pôvodne federálny) zákon o životnom prostredí, ako aj komplexnú právnu úpravu vo sfére narábania s odpadmi (ktorá v SR dovtedy úplne absentovala), zákon o posudzovaní vplyvov na životné prostredie, či zákon o prístupe $\mathrm{k}$ informáciám o ŽP, neskôr integrovaný do komplexnejšie zameraného zákona o prístupe k informáciám (2001).

Ak máme obdobia zvýšenej legislatívnej aktivity konfrontovat' s jednotlivými vládami, potom viac pozitívne ako negatívne môžeme hovorit o prvej ponovembrovej vláde Milana Čiča, 1. vláde Vladimíra Mečiara (ešte ako nominanta VPN), vláde Jána Čarnogurského, vláde J ozefa Moravčíka a 1. vláde Mikuláša Dzurindu. Naopak, 2. a 3. vládu Vladimíra Mečiara, ako aj 1. a 2. vládu Roberta Fica možno označit́ za éru stagnácie až úpadku. Toto konštatovanie sa netýka len legislatívnej sféry, ale aj kádrovo-personálnej politiky, pričom najväčšími "čistkami“, a to v radoch nielen vedúcich, ale aj nižšie postavených odborných pracovníkov v rezorte ŽP, sa vyznačovali vlády pod vedením Vladimíra Mečiara a Roberta Fica, za ktorého MŽP SR, zverené do rúk nominantov Slovenskej národnej strany, zažilo bezprecedentný úpadok, kedy ministerstvo a jeho zložky museli opustit́ mnohí kompetentní pracovníci až po úroveň viacerých zásadových strážcov ochrany prírody!

Financovanie starostlivosti o životné prostredie je chronickým problémom, čo má za následok jednak dlhodobé zaostávanie $v$ budovaní environmentálnej infraštruktúry (najmä na úseku vôd a ich čistenia) či pri odstraňovaní starých environmentálnych zátaží, ale aj minimálnu akcieschopnost' $v$ takých dôležitých oblastiach, ako je napr. štátna ochrana prírody a krajiny, resp. inšpekcia ŽP.

Deficit prostriedkov sa $v$ 90. rokoch minulého storočia dlhodobo prehlboval a alarmujúci bol najmä na prelome tisícročí. Odvtedy došlo k citel'nému zlepšeniu v niektorých oblastiach starostlivosti o ŽP, a to najmä vd’aka zdrojom z EÚ. Tento nárast investícií sa však nedá posudzovat́ mechanicky, či schematicky vzhl'adom na to, že rozsah kompetencií MžP sa postupne menil (v r. 2002 pribudla napr. investične vel'mi náročná vodohospodárska výstavba a protipovodňová ochrana). V niektorých oblastiach (napr. $v$ ochrane prírody) deficit prostriedkov nad'alej pretrváva.

\section{Životné prostredie v agende vlád a politických strán}

Čast́ venovaná životnému prostrediu sa stala viac-menej štandardnou súčastou programových vyhlásení vlád i programov jednotlivých politických strán. Hodné kritiky býva ani nie tak to, čo je $v$ environmentálnych častiach programov uvedené, ako skôr to, čo $v$ nich chýba. EMVO robia pred parlamentnými volbami pravidelne odpočet plnenia environmentálnych programov končiacich vlád a hodnotenie programov kandidujúcich strán (niekedy až po úroveň názorov a postojov jednotlivých kandidátov). Podobne sa EMVO zvyknú vyjadrovat' aj k "zeleným" častiam programov strán a programovým vyhláseniam nových vlád. Zväčša sa pri tom používa anketová metóda zistovania, inokedy napr. analýza relevantných 
hlasovaní v NR SR a pod. Niekedy EMVO organizujú aj predvolebné diskusie s kandidátmi a kandidátkami.

$\mathrm{Na}$ základe dlhodobej skúsenosti možno konštatovat', že programové vyhlásenia a sl'uby vlád a strán $v$ oblasti ŽP sa bud' neplnia, prípadne sa plnia len čiastočne alebo formálne, či dokonca $v$ účelovo deformovanej podobe, ked'sa za aktivitu $v$ prospech ŽP vyhlási aj niečo, čo mu v skutočnosti skôr škodí. Niektoré strany a viacerí kandidáti za poslancov zvyknú legitímny záujem EMVO a verejnosti o svoje zámery a činy jednoducho ignorovat', iní k nemu pristupujú formálne. A tak seriózne vypracovaných reakcií či zodpovedaných anketových otázok býva menšina. Už tento fakt by $v$ skutočne demokratickej krajine stačil na diskvalifikáciu oslovených subjektov.

V skutočnosti životné prostredie $v$ agende ponovembrových vlád - napriek proklamáciám opačného charakteru - nikdy nezískalo postavenie adekvátne jeho významu, náročnosti, prierezovosti a komplexnosti. Ambicióznu podobu starostlivosti o ŽP pritom formulovalo Fórum ochrancov a tvorcov ŽP (neskôr premenované na Ekofórum - pozn. aut.) za reprezentatívnej účasti približne 150 expertov a aktivistov už 8. decembra 1989, kedy navrhlo nielen vytvorenie ústredného orgánu štátnej správy pre životné prostredie na federálnej i národných úrovniach a urýchlené dobudovanie právneho systému v tejto oblasti, ale aj priznanie nadrezortného charakteru tejto problematike (analogicky ekonomickým a právnym aspektom), čo rezultovalo do návrhu, vymenovat́ do čela takéhoto orgánu podpredsedu vlády. Do volieb 1990 bol na Slovensku zodpovedným za jeho kreovanie skutočne podpredseda vlády (Vladimír Ondruš, VPN), ale v skutočnosti sa ústredný orgán takého charakteru u nás nikdy nepodarilo vybudovat'. Možno to súvisí aj s tým, že po Vladimírovi Ondrušovi už žiadny človek na čele tohto rezortu nemal významnejšie politické postavenie $v$ štruktúre svojich materských strán, a teda ani adekvátnu pozíciu pri politickom presadzovaní svojich predstáv (výnimkou bol Peter Žiga, ale ten svoju pozíciu podpredsedu Smeru-SD na pozitívne činy $v$ prospech ŽP nevyužil - skôr naopak) a na krátky čas sa stal podpredsedom vlády Petra Pellegriniho aj László Solymos, ktorý však vo vláde zastupoval najslabšiu koaličnú stranu. Zmenu by mohol priniest́ súčasný minister Ján Budaj ako nominant dominantnej strany súčasnej vládnej koalície (aj ked' podpredsedom vlády sa nestal - pozn. aut.). Ďalším problém je aj to, že predstavy a vízie žiadneho $z$ doterajších ministrov ŽP na Slovensku neboli dostatočne ambiciózne a nedali sa $v$ tomto smere porovnat' so štýlom uvažovania a práce niektorých ich českých kolegov Moldana, Dejmala, Bursíka, Mika a už vôbec nie federálneho ministra Vavrouška.

Ďalšou charakteristickou črtou bolo príliš úzke chápanie ŽP, bez priznania dostatočnej prierezovosti a vplyvu ŽP na ostatné sféry života a spravovania spoločnosti, ktoré je vlastné EÚ minimálne od čias prijatia jej 5. environmentálne akčného programu $v$ r. 1992 a ktoré by zodpovedalo záverom Summitu Zeme v r. 1992 a d’alším relevantným medzinárodným dokumentom. K nedostatočnej ambicióznosti slovenských MŽP nepochybne prispel aj nedostatok vonkajšieho tlaku - zo strany EMVO, médií i širokej verejnosti.

S výnimkou r. 1990 - 1992 a r. 1998 - 2002 v slovenskom parlamente absentovali Zelení. Pritom volebné obdobia, počas ktorých v parlamente pôsobili, možno označit vo sfére slovenskej environmentálnej politiky za najpozitívnejšie (aj ked' nie vždy to bola len zásluha Zelených - pozn. aut.).

V protiklade k spomínanému priúzkemu chápaniu ŽP vystupuje snaha urobit' MŽP zodpovedným za agendu, ktorá je pre ktorýkolvek jednotlivý rezort priširoká, teda za agendu trvalo udržatel'ného rozvoja (TUR), ako aj za niektoré rezortu ŽP neprislúchajúce hospodárske aktivity, ako je napr. vodohospodárska výstavba. 


\section{Životné prostredie na úrovni regiónov, miest a obcí}

Mestá, obce a od čias zásadnej reformy verejnej správy na prelome tisícročí aj regióny (samosprávne kraje) rozhodujú o životnom prostredí vo sfére svojej pôsobnosti čím d'alej tým viac sami. Pozitívom je, že sa tým „rozhodovanie dostáva bližšie k občanovi”. Logicky by mali o svojom vlastnom prostredí vediet́ najviac ludia (a ich volení zástupcovia), ktorí v danom prostredí žijú. Skúsenost' s takýmto prenosom kompetencií v smere zhora nadol však nie je len pozitívna. Ukazuje sa, že na úrovni samosprávy korupcia a klientelizmus „kvitnú“ nemenej ako na centrálnej úrovni. Navyše, riziko subjektivizmu, bezzásadovosti a neodbornosti je na úrovni samosprávy často dokonca vyššie, ako na centrálnej úrovni, ktorá zväčša disponuje väčším odborným zázemím a mala by realitu vnímat' v širších súvislostiach (národných až medzinárodných). Vari najviac sa toto konštatovanie týka rozhodovania o prírodoochranne vzácnych hodnotách na území obcí a miest (maloplošné chránené územia, vzácne stromy a pod.), ktoré majú zo svojej podstaty celospoločenský, a teda nadobecný, charakter.

Na druhej strane sme aj v uplynulých rokoch boli neraz svedkami toho, ako sa vláda a celkovo štátna správa snažili obíst či ignorovat' miestnu samosprávu a legitímne záujmy miestnych obyvatel'ov, nedemokraticky presadzujúc antienvironmentálne zámery (napr. plánovaná vel'kokapacitná skládka odpadu v Pezinku, nelegálne predlžovanie životnosti skládky v Považskom Chlmci, snaha o usporiadanie zimných olympijských hier na území národných parkov, či záujem o táažbu zlata a uránu zdraviu nebezpečnými metódami v blízkosti Košíc, Kremnice, Detvy a pod.).

\section{Životné prostredie a hospodárstvo}

Stav životného prostredia a charakter ekonomiky fungujú do značnej miery ako spojené nádoby. Neefektívna, na tažký priemysel a na priemyselné pol'nohospodárstvo orientovaná slovenská ekonomika spolu s absentujúcou environmentálnou infraštruktúrou spred novembra 1989 bola celkom logicky obrovským devastátorom ŽP. Environmentalisti, ochranári i velká čast́ verejnosti preto v súvislosti s transformáciou ekonomiky po r. 1989 oprávnene očakávali, že sa tento stav bude urýchlene a programovo menit. Jedným z výsledkov transformácie slovenskej ekonomiky a spoločnosti v prvej polovici 90 . rokov 20. storočia bola aj zmena (modernizácia) celej hospodárskej štruktúry a štruktúry tvorby HDP, charakterizovaná výrazným poklesom vo sfére výrobných odvetví (primárna a sekundárna sféra) a nárastom terciérnej a kvartérnej sféry. Po 30 rokoch však môžeme a musíme konštatovat', že táto klúčová zmena strategického charakteru sa uskutočnila len čiastočne, v rozsahu a híbke, ktoré v žiadnom prípade nemožno označit́ ako dostatočné. $V$ prvom rade, nepodarilo sa dostatočne zmenit́ energeticky a surovinovo náročnú a environmentálne závadnú štruktúru slovenského priemyslu. S výnimkou Niklovej hute v Seredi, Železorudných baní v Rudňanoch, táažby a spracovania antimónu v Nízkych Tatrách, niektorých magnezitiek na východnom Slovensku a pár d'alších podnikov zostala väčšina problematických prevádzok tohto druhu fungovat', pričom ani ich čiastočná modernizácia nedokázala (ani nemohla) zásadne zmenit' ich nežiaduce charakteristiky. Za všetky spomeňme aspoň hlinikáreň v Žiari nad Hronom a Východoslovenské železiarne (dnes U.S. Steel) v Košiciach. Zásadnejšou transformáciou prešiel chemický priemysel, ale jeho „bašty“ zostali taktiež viac-menej zachované. Vari najväčšími štrukturálnymi zmenami prešlo (aj ked’ nie z primárne environmentálnych dôvodov, ale najmä pre rozpad dovtedajších trhov) strojárenstvo, ked' z výroby zbraní sa jeho t́ažisko prenieslo do výroby osobných automobilov. Energetika sa nevzdala ani dobudovania Vodného diela Gabčíkovo a niektorých d’alších hydroenergetických projektov, ani väčšiny klasických zdrojov energie (od nerentabilnej t́ažby a zdraviu škodlivého spal'ovania nekvalitného uhlia ustupujeme až v posledných rokoch - pozn. aut.), ani dostavby Jadrovej elektrárne Mochovce. V čom naopak Slovensko nad’alej zaostáva, je oblast́ energetických úspor, 
vrátane zatepl'ovania budov a efektívneho využívania vhodných obnovitel'ných zdrojov. Z týchto dôvodov pretrváva aj environmentálna škodlivost' a rizikovost́ výroby elektrickej energie na Slovensku, ako aj relatívne nízka energetická a surovinová účinnost', ktorá je v prepočte na jednotku HDP stále ešte citel'ne nižšia ako v technologicky najvyspelejších krajinách. Práve nadmerné zakonzervovanie nevyhovujúcej výrobnej štruktúry na Slovensku je možné označit' za jeden z najväčších zdrojov frustrácie ( nielen environmentalistov) z výsledkov transformácie slovenskej ekonomiky $\vee 90$. rokoch minulého storočia, negatívne dôsledky čoho znášame dodnes (a to nielen vo sfére ŽP, ale aj čo sa týka zranitel'nosti celej ekonomiky, čo plasticky ukázala aj nedávna koronakríza).

Vzt́ah pol'nohospodárstva k ŽP bol o niečo priaznivejší, aj ked'samotní pol'nohospodári to hodnotia skôr ako negatívum, lebo to so sebou prinieslo aj pokles pol'nohospodárskej produkcie. Najmä v prvej dekáde po r. 1989 výrazne klesla spotreba priemyselných hnojív a ochranných chemických prostriedkov, čo prirodzene prispelo k ozdraveniu pôd, vôd, bioty i celého potravinového ret́azca (aj ked'sa tým, na druhej strane, znížili hektárové výnosy pozn. aut.). Celkovo došlo, najmä v prvých kokoch po r. 1989, k extenzifikácii pol'nohospodárstva a čiastočnému návratu prítomnosti zelene a drobného živočišstva do pol'nohospodárskej krajiny. Pokračovala tiež transformácia časti ornej pôdy na trvalé trávne porasty a les. Trvalý a nedostatočne regulovaný záber často vel'mi kvalitných pol'nohospodárskych pôd išiel na vrub výstavby - už nie panelových sídlisk a rozlahlých pol'nohospodárskych dvorov, ale vodných diel, automobiliek, dial'nic, priemyselných parkov a logistických či obchodných centier. Opustené výrobné a tažobné komplexy sa naopak zväčša nechávali a nechávajú chátrat' za vzniku devastovaných plôch a neúžitkov (tzv. brownfields).

Zmeny v doprave charakterizuje ústup environmentálne priaznivejších foriem (najmä železničnej a celkovo hromadnej dopravy) na úkor rozvoja environmentálne závadnejšej individuálnej automobilovej dopravy, čo je alarmujúce najmä v mestách, vrátane Bratislavy. Čiastočne to kompenzuje skutočnost', že prevádzka moderných automobilov sa stáva voči ŽP šetrnejšia (s výnimkou rastúcej exploatácie prírodných území terénnymi automobilmi, „štvorkolkami“, motorkami, snežnými skútrami a pod.).

\section{Životné prostredie, hlavní spoločenskí aktéri a spoločnost' ako ce- lok}

\section{Médiá a občiansky environmentálny aktivizmus}

Médiá zaznamenali za uplynulé tri desat́ročia obrovské zmeny po obsahovej i formálnej stránke. Mnohé z týchto zmien boli kladné. Napriek tomu je $v$ ich prípade deficit zmysluplnej aktivity pri pozitívnom ovplyvňovaní verejnej mienky, podpore kritického myslenia a tvorbe hodnotovo orientovanej, životaschopnej a akcieschopnej občianskej spoločnosti stále vel'mi citel'ný. Možno konštatovat', že médiá zohrávajú v tomto smere ambivalentnú úlohu. Tzv. verejnoprávne médiá (najmä elektronické) sa v období autoritatívnych vlád Vladimíra Mečiara správali výrazne provládne a zároveň podozrievavo až odmietavo voči občianskym iniciatívam, mimovládnym organizáciám i celkovo voči nezávislému spôsobu uvažovania a vyjadrovania. Najmä v r. 1992 - 1998 mali občianski aktivisti minimálnu šancu preniknút do verejnoprávnej Slovenskej televízie. $V$ tom čase bola direktívnym zásahom zhora zrušená i vysoko sledovaná, pravidelná, environmentálne a investigatívne zameraná publicistická relácia Slovenskej televízie Eko d’alej. Ďalším príznačným neduhom tých čias bolo, že informácie o aktuálnych kauzách, týkajúcich sa životného prostredia, sa podávali tendenčne a jednostranne, bez možnosti efektívne uplatnit' alternatívny, alebo opačný názor zo strany EMVO. Určitú zmenu v tomto smere znamenala nielen zmena vlády v jeseni 1998, 
ale aj postupný vznik viacerých súkromných a miestnych televízií, čo prinieslo aj objavenie sa niektorých relácií investigatívneho, či diskusného charakteru, ako napríklad Reportéri, Pod lampou (neskôr Lampa) či Večera s Havranom. Nedostatky v PR, čiže v (seba)propagácii a komunikácii s verejnostou, sú však aj na strane samotných EMVO a občianskych iniciatív. Pozitívnu výnimku predstavuje Greenpeace Slovensko, čiastočne aj Lesoochranárske zoskupenie VLK, Ekofórum, Sosna, Živica, WWF Slovensko, Centrum pre podporu trvalo udržatel'ných aktivít (CEPTA), Bratislavské regionálne ochranárske združenie (BROZ), SOS/BirdLife, Slovenský ochranársky snem (S-O-S), či Cyklokoalícia, ako aj občianske iniciatívy Piatky pre budúcnost', Aliancia za klímu, Znepokojené matky, My sme les, Za našu vodu a i. $V$ minulosti tiež Spoločnost' pre trvalo udržatel'ný život $v \mathrm{SR}$, Ĺudia a voda, Slovenský zväz ochrancov prírody a krajiny, Slatinka, Za živé rieky, Centrum pre podporu miestnych aktivít/CEPA, Slovenská riečna siet', Agentúra Poniklec, A-Projekt, Pospolitost' harmonického života, Environmental Training Program (ETP) Slovensko, Slovenská riečna siet', REC Slovensko, Karpatské ochranárske združenie altruistov (KOZA), Za Matku Zem a niektoré d'alšie.

Donedávna systematicky sledoval situáciu aj v tejto oblasti Inštitút pre verejné otázky (IVO), či už prostredníctvom ad hoc vydávaných publikácií, alebo pravidelnej, každoročne publikovanej Súhrnnej správy o stave spoločnosti, ktorá spravidla obsahovala aj kapitolu Životné prostredie a trvalo udržatel'ný rozvoj. Problematike sa priebežne venuje aj Centrum pre filantropiu, EKOPOLIS, S-O-S, STUŽ/SR a niektoré d'alšie MVO či združenia, najmä thinktankového a nadačného typu.

Nové formy a priestory komunikácie priniesol Internet. Tretí sektor na Slovensku využíval a využíva v tomto smere najmä služby Changenetu a Ekofóra, stránku www.ochranari.sk a špecializovaných skupín na Facebooku. Stále populárnejším žurnalistickým útvarom, dostupným širokej verejnosti, sa stávajú blogy.

\section{Školy a mimoškolská výchova $k$ občianskemu aktivizmu}

Ak súhlasíme s tvrdením, že rozhodujúci vplyv na naše uvažovanie a konanie má výchova a vzdelanie, potom $v$ prípade vztahu $k$ prírode a a životnému prostrediu to platí dvojnásobne.

V oblasti environmentálne výchovy, vzdelávania a osvety (EVVO) nastal čiastočný aj ked' absolútne nie dostatočný - pokrok, ktorý, okrem digitalizácie a tým aj svojím rozsahom enormných a lahko dostupných informácií, priniesla aj zmena osnov, ich prispôsobenie regionálnym podmienkam, rastúci záujem o globálne problémy, nové fakultatívne činnosti, sútaže a pod. prakticky na všetkých stupňoch a druhoch škôl. Viackrát sa objavili a následne "sublimovali" spoločné iniciatívy ministerstva školstva a ministerstva životného prostredia v oblasti environmentálnej výchovy a vzdelávania. Systematická výchova k občianskemu aktivizmu či aktivizmu v prospech životného prostredia dosial' na našich školách absentuje. Chronickým problémom je nedostatok kvalifikovaných učitel'ov, deficit financií ako aj rastúca byrokratická zátaž a s tým súvisiaci nedostatok času a následne i vôle: napríklad na organizovanie pobytov žiakov priamo $v$ prírode, ale tiež na celkové podnecovania tvorivosti a aktivizmu. Malá pozornost' sa venuje riešeniu modelových situácií, či prizývaniu externých lektorov a prednášajúcich z praxe, občianskych aktivistov a lídrov environmentálnych MVO nevynímajúc.

Mimoškolská EVVO zaznamenala za uplynulé dve desat'ročia na Slovensku skôr úpadok, ako pokrok. Toto konštatovanie sa týka v prvom rade prístupu zo strany štátu. Kým $\checkmark 90$. rokoch minulého storočia pôsobilo na Slovensku niekolko stredísk environmentálnej výchovy, dnes z nich zostalo už len jediné! Celkovo v tejto oblasti profesionálne pôsobí mno- 
honásobne menej lúdí v porovnaní so susednou Českou republikou. Situáciu čiastočne zachraňuje mimovládny sektor. Takto zamerané MVO zastrešuje strešná organizácia s názvom Špirála a najviac aktivít v tejto oblasti vyvíja OZ Živica.

\section{Veda a občiansky environmentálny aktivizmus}

Oficiálna veda na Slovensku je voči ochranárskym aktivitám dost' rezervovaná. Určitú výnimku $v$ tomto smere predstavovala $v$ minulosti kauza Tatry. Najmä v období tesne po vetrovej kalamite v novembri 2004, kedy ako Senát Univerzity Komenského, tak aj Snem Slovenskej akadémie vied podporili požiadavky Mimovládneho výboru Naše Tatry, adresované Vláde SR. V apríli 2010 Snem SAV odmietol návrh novej zonácie TANAP-u, ktorý by, $\checkmark$ prípade svojho prijatia, znamenal d’alšiu urbanizáciu a komercionalizáciu nášho najstaršieho národného parku.

Za prevažne vedeckú ustanovizeň možno považovat' aj Národný komitét IUCN. Ten v jeseni 2008 oficiálne protestoval proti devastácii Biosférickej rezervácie Tatry výstavbou nových zjazdoviek a d'alšími antiekologickými aktivitami. V r. 2010 sa aj odborná verejnost' zmobilizovalo $v$ súvislosti $\mathrm{s}$ likvidáciou samostatnosti MŽP SR a $\mathrm{s}$ už spomínaným návrhom zonácie TANAPu. $V$ neskorších rokoch najmä v súvislosti $s$ devastačnou tažbou $v$ lesoch a znečistovaním podzemných vôd Žitného ostrova.

Ostatné aktivity vedcov majú skôr individuálny, či skupinový, ale nie inštitucionálny charakter. Či už ide o iniciatívu 108 vedcov za zabránenie tažby dreva v Národnej prírodnej rezervácii Tichá a Kôprová dolina, alebo o podobne početnú iniciatívu vedcov proti chemickým postrekom, aplikovaným na území niektorých národných parkov (najmä NAPANT-u).

V r. 2016 Predsedníctvo Slovenskej akadémie vied (SAV) podporilo vznik Národného parku Podunajsko a v r. 2019 SAV ako aj najvýznamnejšie slovenské univerzity verejne podporili klimatických aktivistov/aktivistky a ich iniciatívu Piatky pre budúcnost́. Deficity verejnej angažovanosti zo strany vrcholných vedeckých inštitúcií na Slovensku sú súčastou širšieho problému vzt́ahu vedy $\mathrm{k}$ hodnotám, $\mathrm{k}$ veciam verejným a $\mathrm{k}$ občianskej angažovanosti, o ktorom sa na Slovensku dosial' takmer vôbec nediskutovalo. Jednou z malých výnimiek bol seminár a následne zborník k 20. výročiu vydania publikácie Bratislava/nahlas (Huba, M., Ira,V., Šuška, P. (eds.) 2008).

Akýmsi mostom medzi vedeckou sférou a MVO sú tzv. think-tanky. V prvých dvoch desat́ročiach po r. 1989 z nich vyrástol seriózny partner a vážny konkurent SAV i univerzít v oblasti zberu, spracovania i distribúcie závažných informácií ako aj v oblasti inovatívnosti nazerania, podpory kritického, alternatívneho myslenia, generovania nových ideí, vízií a pod. Zdá sa však, že $v$ poslednom desatročí pomaly ustupujú do úzadia, čo súvisí zrejme aj $s$ nedostatkom finančných prostriedkov na ich činnost'.

\section{Spätná väzba: pohl'ad verejnosti}

Ako sa vyvíja postoj radových občanov, či širokej verejnosti k environmentálnym problémom, environmentálne zameraným politikám a následne $\mathrm{k}$ ochranárskym aktivitám a ich organizovanej forme prostredníctvom EMVO? Čo sa týka prvej a druhej časti otázky, je na mieste pripomenút si, že pred 30 rokmi verejnost' považovala životné prostredie za top prioritu. Na otázku "Ktoré spoločenské problémy je podl'a Vás potrebné riešit́ v prvom rade?" v apríli 1990 odpovedalo najviac respondentov (19\%), že je to podl'a nich devastácia ŽP. Už v októbri toho istého roku si to však myslelo iba $7 \%$ a ŽP sa "prepadlo" v rebričku dôležitosti 
z 1. na 6. miesto (CVSP, 1990). Podobne tomu bolo na Slovensku aj s preferenciami environmentálne orientovanej Strany zelených, ktorú vo februári 1990 chcelo volit' $16 \%$ opýtaných (2. až 3. miesto medzi stranami), pričom v júnových volbách r. 1990 jej dalo hlas iba $3,48 \%$ voličov a do slovenského parlamentu sa dostala so šiestimi mandátmi ako najslabšia z parlamentných strán. Čo sa týka tretej časti otázky, vývoj verejnej mienky je priaznivejší. Ako ukazujú sporadické výskumy na túto tému, je tento postoj verejnosti k ochranárskym aktivitám väčšinovo kladný a verejnost' ich väčšinovo považuje za dôveryhodné. Aj tu však platí čosi ako zákonitost', že postoj verejnosti je tým pozitívnejší, čím všeobecnejšie otázky na tieto aktivity či problémy formulujeme a komplikuje sa $v$ závislosti od konkretizácie jednotlivých sfér, tém a/alebo káuz. Druhým problémom je, že podpora zo strany verejnosti zostáva vo velkej väčšine len vo verbálnej, platonickej podobe. Skutočne spontánneho záujmu a hmatatel'nej, aktívnej podpory zo strany občana/verejnosti je málo a početne výrazne zaostáva za záujmom o riešenie napr. rýdzo politických káuz, súvisiacich s korupciou a pod. Kým na demonštráciách iniciatívy Za slušné Slovensko sa v Bratislave v r. 2018 opakovane zúčastnili desat́tisíce ludí, na zhromaždení za prepustenie zadržiavaných aktivistov Greenpeace v tom istom roku, či na zhromaždeniach Piatky pre budúcnost́ v r. 2019 to boli rádovo len stovky účastníkov a účastníčok a iba v septembri 2019 ich počet presiahol tisícku. Pre porovnanie, na ochranárskej živej retáazi za Národný park Podunajsko sa vo februári 1990 zúčastnilo okolo 60000 ludí. Dôvodov tohto poklesu záujmu o priamu participáciu je iste viacero. Okrem rozdrobenosti ochranárskej scény je to aj určitá únava a pocit márnosti až frustrácie z opakujúcich sa neúspechov. Výstižným upozornením na (ne)kvalitu vzt́ahu občan-moc-demokracia bol happening s názvom Hádzanie hrachu o stenu, ked'sa hádzal skutočný hrach o skutočnú stenu bratislavského Magistrátu, na pripomenutie toho, že neraz i dlhotrvajúce a početne zastúpené občianske aktivity $v$ prospech životného prostredia vychádzajú v hlavnom meste Slovenska nazmar. Podobne ako aj v iných oblastiach, aj tu sa masové aktivity čoraz viac presúvajú do virtuálneho priestoru a od zhromaždení k petíciám a do facebookových skupín.

Najväčšia petícia s viac ako 113000 podpismi, ktorú iniciovala koncom minulého desatročia slovenská pobočka Greenpeace, sa týkala zákazu tažba zlata a uránu kyanidovou metódou. Ďalšie dve sa týkali lesov. Lesoochranárske zoskupenie VLK zozbieralo do tejto chvíle viac ako 100000 podpisov pod petíciu NIČ - na podporu zvýšenia výmery bezzásahových území. Iniciatíva My sme les zasa získala v rekordne krátkom čase cca 70000 podpisov pod internetovú petíciu za lepšiu ochranu lesov.

Facebooková skupina Slovenský ochranársky snem má k dnešnému dňu viac ako 2 400 členov a cca 1600 žiadatel'ov/žiadateliek o členstvo.

Vzt́ah k politike je zo strany EMVO determinovaný v prvom rade skutočnostou, že z ich štatútu a poslania vyplýva, že by mali byt́ od politických (podobne ako aj od podnikatel'ských a decízno-byrokratických) subjektov nezávislé. Najväčšie vzopätia vo sfére MVO i celej občianskej spoločnosti sa viažu na začiatok popisovaného 30-ročného obdobia, teda na prelom rokov 1989 a 1990, na druhú polovicu 90. rokov 20. storočia, kedy sa tretí sektor aktívne zapojil do úsilia o demokratizáciu spoločenských (i politických) pomerov na Slovensku (pozri napr. Snajdr, E., 2008) a na r. 2017 až 2019, kedy občianska spoločnost́ demonštrovala proti kriminalite, nespravodlivosti a korupcii a za celkovú očistu politického a spoločenského života.

Environmentálne, spolu s ludskoprávnymi mimovládnymi organizáciami sú spomedzi súčastí tretieho sektoru na Slovensku tradične najzásadovejšie a najradikálnejšie. Radikalizmus na slovenský spôsob bol však doteraz vel'mi umiernený, akademický či konštruktívny. Niekedy možno až príliš, čo ulahčuje život devastátorom životného prostredia a nepriatelom 
občianskej spoločnosti. Určitú zmenu v tomto smere slubujú hnutia ako Extinction Rebellion či Bod obratu.

Za špecifický problém nedostatočného záujmu občanov o problémy životného prostredia možno považovat' aj rastúcu inštrumentalizáciu, byrokratizáciu a "rezortizáciu" environmentálnej politiky na úkor hodnotových, vztáahových či životnoštýlových aspektov. Priúzke, miestami až technokratické chápanie problematiky ŽP - ako čisto organizačno-legislatívnotechnologického problému - ho odcudzuje bežnému človeku a vzbudzuje ilúziu, že riešenie environmentálnych problémov je vo výlučnej kompetencii úradov, expertov, investorov, skrátka „niekoho iného, ako som ja“.

Na druhej strane, vymedzenie ŽP len ako rezortného problému ho zbavuje širších súvislostí a väzieb, čo okrem iného vedie $\mathrm{k}$ tendencii odstraňovat́ následky, a nie príčiny. Pritom skutočným východiskom môže byt' len posudzovanie a riešenie environmentálnych problémov $v$ súčinnosti s ekonomickými, sociálnymi, politickými a d’alšími dimenziami rozvoja. Na tomto poznaní sa zakladá koncepcia trvalo udržatel'ného rozvoja (resp. spôsobu života).

Postoje verejnosti k problematike ŽP a ENVO sa, žial', zistúujú len sporadicky, a nie systematicky. Pred časom sa danou problematikou zaoberali sociológovia J. Klocoková a M. Tí̌ík (2009) a Tížik (2010). Vychádzajúc najmä z reprezentatívnych výskumov verejnej mienky Eurobarometer z r. 2004 a 2007 a z Výskumu európskych hodnôt z. r. 1991, 1999 a 2008 dospeli o.i. k nasledujúcim zisteniam: Čo sa týka reflektovania ŽP na tej najvšeobecnejšej úrovni, respondenti z nových členských krajín EÚ a zvlášt́ zo Slovenska výrazne častejšie uvádzali ako hlavnú asociáciu s pojmom ŽP zelenú a príjemnú krajinu, ako aj ochranu prírody a využívanie prírodných zdrojov. Na druhej strane, v prípade slovenských respondentov sa ŽP v porovnaní s priemerom EÚ ovela menej asociovalo so znečistením miest či klimatickými zmenami.

$\checkmark$ poradí pocitovaných problémov a hrozieb sa na Slovensku na prvom mieste umiestnili problémy súvisiace so znečistením jednotlivých zložiek ŽP (voda, ovzdušie, ako aj prírodné a človekom spôsobené katastrofy). Obavy z nepriaznivých klimatických zmien síce na Slovensku nie sú také velké ako v priemere za celú EÚ, ale majú výrazne rastúcu tendenciu a dnes už aj na Slovensku vedú rebríček vnímaných environmentálnych problémov (tesne pred prírodnými katastrofami).

Vnímanie dôležitosti vplyvu ŽP na kvalitu života sa v prípade slovenských respondentov príliš nelíšilo od priemeru EÚ a v rokoch 2004 - 2007 podiel tých, ktorí tento vplyv označili za dôležitý, vzrástol zo $74 \%$ na $83 \%$.

Je pozoruhodné, že výrazná väčšina Európanov by dala prednost' environmentálnym opatreniam pred zvyšovaním ekonomickej konkurencieschopnosti, ako aj to, že postoj respondentov zo SR bol v tomto smere ešte mierne proenvironmentálnejší, než postoj „priemerného Európana“. Ešte pozitívnejšie dopadlo Slovensko v odpovedi na otázku, či by sa pokrok mal merat́ najmä ekonomickými indikátormi, alebo komplexom indikátorov (vrátane environmentálnych), kde sa za druhú možnost́ vyjadrilo viac ako 80 \% opýtaných zo Slovenska.

Vyššie uvedené $\mathrm{i}$ niektoré d’alšie zistenia sú $v$ protiklade $s$ reálnou mariginalizáciou environmentálnej problematiky a problematiky trvalej udržatel'nosti v politickej agende doterajších vlád, väčšiny politických strán i v rámci verejného diskurzu a môžu byt́ zdrojom opatrného optimizmu. Adjektívum „opatrný“ je na mieste už aj preto, že v protiklade k vyššiu uvedeným postojom deklarovaným na vel'mi všeobecnej úrovni, na druhej strane 
dlhodobo klesá ochota podporit' ochranu ŽP na úkor vlastných príjmov a zodpovednost́ za túto agendu sa $v$ názoroch slovenských respondentov presúva na plecia vlády, štátneho rozpočtu, EÚ a pod., ako aj na plecia pôvodcov znečistenia, najmä priemyslu. Až 84 \% respondentov zo Slovenska však napriek tomu nad'alej verí v dôležitost' úlohy jednotlivca vo sfére ŽP. Spomedzi aktivít, ktorými môže jednotlivec prispiet́ k ochrane ŽP, respondenti z väčšiny krajín EÚ (vrátane Slovenska) uvádzali na prvom mieste triedenie komunálneho odpadu, nasledované úsporou vody a redukciou spotreby energie. Odborníci však tento druh aktivít označujú ako pasívny a $v$ prípade šetrenia motivovaný viac ekonomicky, ako environmentálne. Postrádajú aktívnejšie a citel'nejšie formy dobrovol'ného sebaobmedzovania $\vee$ prospech ŽP (napr. obmedzenie jazdy autom).

Čo je vari najviac znepokojujúci vývoj, dokumentovaný citovanými výskumami, to je dlhodobý pokles osobnej účasti a aktívnej podpory (napr. členské príspevky, brigádnická práca, aktívna participácia účast' a pod.) aktivít dobrovol'níckych združení, pôsobiacich $v$ prospech ŽP, pričom práve environmentálne organizácie patria medzi tie, v ktorých sa ludia na Slovensku najmenej dobrovol'ne angažujú. Na druhej strane z výskumov vyplýva, že EMVO sa na Slovensku tešia značnej dôvere, ked'ich v rokoch 2004 a 2007 (ako aj v nasledujúcom desat́ročí) opakovane cca polovica respondentov označila za najdôveryhodnejší zdroj informácií o ŽP. Slovensko v tomto smere dokonca vysoko prevyšuje európsky priemer.

$\checkmark$ posledných rokov dve anketové zistenia na túto tému realizoval $v$ radoch environmentalistov Slovenský ochranársky snem (pozri Huba, Trubíniová, eds., 2019).

Aj vyššie uvedené názory dokumentujú, že stav a vývoj ŽP a EMVO nie je zložitý a protirečivý fenomén len "sám o sebe“, ale aj vo vnímaní zo strany verejnosti ako aj v interpretácii tohto vnímania a jeho príčin.

\section{Medzinárodné postavenie Slovenska vo sfére životného prostredia}

Ešte ako súčast' Československa sme boli v období 1989 - 1992 považovaní za lídrov spomedzi krajín strednej a východnej Európy, čo sa týka domácich i medzinárodných aktivít $\checkmark$ prospech ŽP. Medzi hlavné dôvody patrilo pôsobenie osobností typu Bedřicha Moldana, J osefa Vavrouška, Ivana Dejmala, Ivana Ryndu, Pavla Šremera, Jana Káru, Juraja Mesíka, Mikuláša Hubu a d’alších vo vrcholových či vysokých pozíciách vo vtedajších vládnych a parlamentných štruktúrach, ich pomerne kvalitné expertné zázemie, ako aj „ozvena“ vplyvného ochranárskeho hnutia z predrevolučného obdobia. Ale boli to najmä oprávnené líderské ambície a konkrétne iniciatívy či aktivity, ktoré z našej krajiny vychádzali, o.i. a j v súvislosti s usporiadaním prvej pan-európskej konferencie ministrov životného prostredia v Dobříši pri Prahe či s prípravou Konferencie OSN o životnom prostredí a rozvoji v Rio de Janeiro (Bedřich Moldan bol podpredsedom tohto podujatia).

Po volbách 1992 sa mnoho podstatného zmenilo. Zanikol Federálny výbor pre životné prostredie a čoskoro na to sa rozpadlo aj samotné Československo, čím pre Slovensko prestal byt' bezprostredne relevantný aj dovtedy inšpiratívny ambiciózny program a pozitívny príklad českého MŽP. Medzinárodný význam si nad'alej udržiavalo iba mimovládne ochranárske hnutie.

Koalícia HZDS so SNS a ZRS v 90-tych rokoch minulého storočia bola "zaručenou cestou" do medzinárodnej izolácie. A nemohla sa tomu vyhnút ani oblast' ŽP, hoci formálne bolo Slovensko ako nástupnícky štát po bývalej ČSFR zastúpené vo všetkých relevantných štruktúrach. Čo sa stratilo, bola dôveryhodnost', záujem, kompetentnost́ a iniciatíva. Situáciu či- 
astočne zachraňovali jednotlivci na nižších postoch, ktorí neprestali spolupracovat' s akademickou a mimovládnou sférou (napr. $v$ oblasti posudzovania vplyvov na ŽP a prípravy príslušných právnych noriem, alebo $\vee$ oblasti ochrany biodiverzity: v r. 1997 sa v Bratislave uskutočnila významná 4. konferencia strán Dohovoru o biodiverzite), či prípravy materiálov strategického charakteru (Environmentálna politika SR, príprava Národnej stratégie trvalo udržatel'ného rozvoja SR a i.) .

K určitému oživeniu prišlo po volbách v r. 1998, kedy sa ministrom ŽP stal medzinárodne skúsený vedec a pedagóg - geograf a krajinný ekológ László Miklós. Navyše, došlo k uzavretiu dohody medzi MŽP a združením EMVO Ekofórum, z ktorej rezultovalo zlepšenie vzájomnej spolupráce vládnych a mimovládnych štruktúr. To d'alej posilnilo prijatie do OECD a integračné úsilie Slovenska v rámci predvstupového procesu do EÚ. Vyvrcholením tohto obdobia mohla byt́ oficiálna slovenská účast' na Svetovom summite o TUR v J ohannesburgu v r. 2002. Z viacerých príčin však táto príležitost' zostala nedostatočne využitá.

Od 1. mája 2004 sme riadnymi členmi EÚ, s čím súvisí aj naša plná integrácia do európskej environmentálnej politiky. Podobne ako v iných oblastiach, aj tu trpíme nedostatkom kompetentných kádrov, čo sa ešte viac prejavilo po volbách 2006 , kedy sa ich rady necitlivými politickými zásahmi d’alej preriedili a ani jeden z troch ministrov životného prostredia za SNS nemal adekvátne odborné schopnosti a medzinárodné skúsenosti. Žial', podobné konštatovanie sa týkalo aj časti štátnych tajomníkov MŽP a generálnych riaditel'ov sekcií. A tak situáciu neraz zachraňovali a zachraňujú len "poslední mohykáni”, ktorí sa $v$ štruktúrach MŽP nejakým zázrakom ešte udržali a schopní ludia prevažne z mladšej generácie, ktorí sa tam dostali najmä v súvislosti so slovenským predsedníctvom v Rade EÚ a vznikom Inštitútu environmentálnej politiky.

Určitým prienikom Slovenska aj do medzinárodnej diskusie o ŽP bolo slovenské predsedníctvo v Rade EÚ v r. 2016, pôsobenie dvoch slovenských europoslancov - environmentalistov od eurovolieb v r. 2019 či vystúpenie prezidentky Zuzany Čaputovej na klimatickom summite na pôde OSN v r. 2019, ako aj skutočnost', že prezidentka považuje ochranu ŽP za jednu zo svojich troch najvyšších priorít.

\section{Záver}

Životné prostredie, organizácie a iniciatívy na jeho ochranu, ako aj percepcia tejto problematiky zo strany verejnosti prešli za uplynulých 30 rokov zložitým vývojom. Vari najvýstižnejšou charakteristikou tohto vývoja je to, že bol nejednoznačný. Pokrok pri znižovaní znečistenia ovzdušia, vôd a d’alších zložiek životného prostredia sprevádzala bezprecedentná neúcta $\mathrm{k}$ iným jeho zložkám, najmä $\mathrm{k}$ zeleni a úrodným orným pôdam, celkové dlhodobé podfinancovanie starostlivosti o ŽP a zaostávanie $v$ budovaní environmentálnej infraštruktúry (najmä kanalizácií a čistiarní odpadových vôd) ako aj riešenia problematiky starých environmentálnych zátaží.

Výrazný nárast výmery chránených území bol konfrontovaný s opakovane prezentovaným nepochopením samotného zmyslu ochrany prírody a krajiny, a to aj zo strany kompetentných riadiacich pracovníkov $v$ sektore štátnej správy a samosprávy, o čom svedčí o.i. aj vypustenie ochrany charakteristického vzhl'adu krajinu zo zákona o ochrane prírody a krajiny.

$\checkmark$ celej tejto sfére je citel'ný nedostatok systematickej a hodnotovo orientovanej environmentálne výchovy, vzdelávania a osvety. 
Vznik inštitúcií a desiatok právnych noriem na ochranu životného prostredia bol nevyhnutným predpokladom nielen systematickej starostlivost́ oň, ale aj akceptácie Slovenska zo strany zahraničia. Na druhej strane je alarmujúce, že relevantné inštitúcie sa pod rôznymi tlakmi stali neraz viac arbitrami väčšej devastácie prírody a životného prostredia, než jeho ochrancami (pozri napr. kauzy Tatry, Pezinok, emisné kvóty a mnohé d’alšie).

Stále častejšie používanie pojmov životné prostredie či trvalo udržatel'ný rozvoj sa spája s obsahovým vyprázdňovaním týchto pojmov a pôsobí skôr inflačne, ako motivačne, dôveryhodne a autenticky.

Ani vývoj vo sfére environmentálne zameraných mimovládnych organizácií (EMVO) nemožno hodnotit' jednoznačne. Na jednej strane mnohonásobne vzrástol ich počet a v mnohých prípadoch aj profesionalita ich manažmentu, na druhej strane z velkej časti stratili spontánny, dobrovol'nícky charakter. A napokon, nejednoznačné sú aj postoje, reakcie a názory verejnosti na túto problematiku. Ako ukazujú porovnania na základe medzinárodných sledovaní, možno označit slovenskú verejnost́ v rámci EÚ za nadštandardne „environmentálne osvietenú". Opakovane deklaruje velký význam problematiky životného prostredia, pripisuje jeho ochrane väčší zmysel ako zvyšovaniu ekonomickej konkurencieschopnosti a environmentálne mimovládne organizácie považuje za najdôveryhodnejšie zdroje informácií o životnom prostredí. V praktickom správaní sa jednotlivcov i verejnosti ako celku je to však podstatne horšie: od konkrétnych ukážok narábania so zeleňou či komunálnym odpadom, cez nešetrné vzorce správania a neraz nepochopitel'ne nešetrný životný štýl, až po „nezelené“ volebné preferencie a klesajúcu ochotu venovat' čast' svojho vol'ného času či finančných prostriedkov $v$ prospech aktivít na ochranu prírody a životného prostredia.

\section{Pod'akovanie:}

Príspevok vznikol aj vd’aka podpore GP VEGA 2/0013/18 a KEGA: 015UKF-4/2019.

\section{Literatúra:}

- Centrum pre výskum spoločenských problémov (1990): Výskum názorov obyvatel'ov SR počas roku 1990, Bratislava. In: Bútora, M., Bútorová, Z. : Volbby 1990: do neprebádaného územia. Denník N, 12. 6. 2020.

- Huba, M. Stručná analýza relevantných aspektov vývoja Slovenska od Konferencie OSN o životnom prostredí a rozvoji. Životné prostredie 2002, roč. 34/2. pp. 61 67.

- Huba, M., Ira V., Šuška (2008): Bratislava/nahlas po 20 rokoch ako výzva Bratislava / nahlas - ako výzva : zborník z odborného seminára $\mathrm{k} 20$. výročiu vydania publikácie. Geografický ústav SAV : STUŽ/SR : ZO Slovenského zväzu ochrancov prírody a krajiny č. 6 a 13 v Bratislave, 2008. $71 \mathrm{~s}$.

- Huba, M., Trubíniová, Ĺ. (eds.): O Slovensku otvorene a nahlas: Ochranárske SOS, STUŽ/SR, Bratislava, 2019, 253 s.

- Klocoková. J. Tížik, M. (2009): Pohl'ad slovenskej verejnosti na životné prostredie a environmentálne problémy. Životné prostredie 43/3, 142 - 148.

- MŽP SR, SAŽP (2016): Životné prostredie Slovenskej republiky v kocke/Environment of the Slovak Republic in Focus. Bratislava, $64 \mathrm{~s}$. 
- MŽP SR (2018): Správa o stave životného prostredia v Slovenskej republike v roku 2018.

- MŽP SR (2020): Národný program znižovania emisií - Slovenská republika.

- SHMU (2018): Hodnotenie kvality ovzdušia v Slovenskej republike (2004 - 2017)

- $\quad$ SHMú (2019): Správa o kvalite ovzdušia v Slovenskej republike 2017.

- Snajdr, D. Nature protests. The end of ecology in Slovakia (culture, place, and nature).

- Washington University Press, Washington 2008.

- Tížik, M. (2010): Názory na životné prostredie na Slovensku a v Českej republike po r. 1989. In: Nováček, P., Huba, M. (eds.) : Udržitelný rozvoj - stav a perspektivy v roce 2010. Sb. přednášek, UPOL, Olomouc, pp. 51 - 75.

- www.enviroportal.sk

- $\quad$ www.euroactiv.sk

Prof. RNDr. Mikuláš Huba, CSc.

Geografický ústav SAV a Spoločnost' pre trvalo udržatel'ný život v Slovenskej republike, Štefánikova 49, 81473 Bratislava 